\title{
ニュートンとリンゴの伝聞文書
}

\section{Newton and the apple}

2010 年 1 月 21 日号 Vol. 463 (274)

アイザック・ニュートンは、 木からリンゴが落ちるのを見 て、重力について考えるよう になったといわれている。こ れはおそらく、科学的発見に 関する逸話の中で最も長く伝 えられてきたものである。こ のほど、この逸話を記録し た最も初期の文献の手書き 原稿が、ネット上で公開され
た。英国学士院が、ほかの いくつかの文献とともに、こ れまでテキスト形式でしか閲 覧できなかったウィリアム． ステュークリーの『アイザッ ク・ニュートン卿の生涯につ いての回想録（1752 年）』 をデジタル画像化したのであ る (http://royalsociety.org/ Turning-the-Pages/参照)。

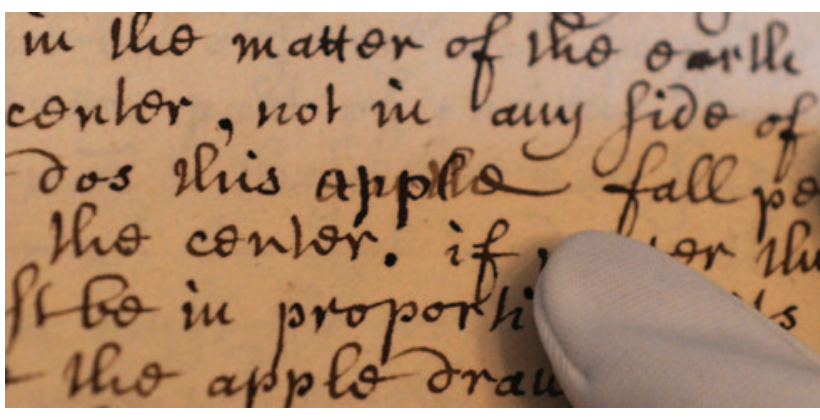

ニュートンと同じ時代を生き たステュークリーは、この本 (写真) で、1726 年にリン ゴの木の下でニュートンと話 をしていたときに本人から聞 いたエピソードとして、「彼
は私に、『重力の概念が頭に 浮かんできたのは、ちょうど こんなときだった』と話して くれました」と記している。

(翻訳 : 三枝小夜子) 